\title{
ANALYSIS OF PROGNOSIS OF LOWLAND RIVER BED EROSION BASED ON GEOTECHNICAL PARAMETERS
}

\author{
AGNIESZKA SMAGA \\ Adam Mickiewicz University, Department of Engineering Geology and Geotechnics, Poznań, Poland. \\ Institute of Geology, Collegium Geologicum, ul. Maków Polnych 16, 61-606 Poznań, \\ e-mail: asmaga@amu.edu.pl
}

\begin{abstract}
The river erosion is a complex process, the dynamics of which is very difficult to predict. Its intensity largely depends on hydraulic conditions of the river channel. However, it is also thought that natural resistance of the subsoil has a great influence on the scale of the erosion process. Predicting the effects of this process is extremely important in the case of constructing a piling structure (for example, artificial reservoirs). The partition of the river channel causes significant lowering of the river channel bed downstream the dam which threatens the stability of hydro technical and engineering (bridges) buildings. To stop this unwanted phenomenon, stabilizing thresholds are built. However, random location of thresholds significantly reduces their effectiveness. Therefore, taking under consideration natural geotechnical conditions of the subsoil appears to be extremely important.

In the light of the current development of in-situ tests in geotechnics, an attempt to use results from these tests to predict the bed erosion rate was made. The analysis includes results from CPTU and DPL tests, which were carried out in the Warta River valley downstream the Jeziorsko reservoir. In the paper, the general diagrams for the procedure of obtaining and processing the data are shown. As a result, the author presents two multidimensional bed erosion rate models built based on hydraulic data and results from CPTU or DPL tests. These models allow taking more effective actions, leading to the neutralization of the effects of the intensive bed erosion process.
\end{abstract}

Key words: CPTU, relative density, bed erosion, river flow

\section{INTRODUCTION}

The process of erosion, transport and deposition of sediments depends mostly on the value of river flow velocity. Sediments are eroded by the flowing water when the velocity of the flow equals a certain value called the critical velocity. The value of this velocity is defined by formulas based on diameters of grains [9]. These two parameters (critical velocity and grain sizes) were commonly used for the erosion process interpretation. However, nowadays scientists start to include other parameters, especially the ones describing the geotechnical conditions of deposits building the river valley. It is thought that strength parameters of soils and physical parameters connected with them have the biggest influence on the erosion rate.

The strength parameters can be estimated from cone penetration tests (CPT). However, the interpretation of CPT is complicated and should involve carrying out drilling and laboratory tests. Considering that the author suggests applying the cone penetration tests parameters directly to the multidimensional model of the erosion rate.

As a physical parameter, relative density was taken under consideration, mostly because the examined section of Warta River valley is built from non-cohesive soils. Furthermore, relative density is a derivative of porosity of soils, which characterise the filtration process in the subsoil and can be obtained from dynamic probing light test (DPL) by applying basic formulas. In view of the above, the spatial variability of this parameter values was used as another geotechnical parameter, which can be correlated with the erosion process and used to build the model.

Accounting for the above, two models of the bed erosion rate downstream the dam consist of CPT parameters or relative density. Furthermore, to fully describe the erosion process, apart from strength and physical parameters, the hydraulic parameter - the river flow $(Q)$ was included in the analysis in both models. That is why created models of the bed erosion rate are tuned for determined values of $Q$ parameter - equal to $40-47 \mathrm{~m}^{3} / \mathrm{s}$. Based on these values 
these models are divided into certain zones (Figs. 4 and 7).

\section{RESEARCH AREA}

The research area was chosen in view of appearance of the intensive bed erosion. Consequently, in- coarse, medium, fine and silty sands (Fig. 2). Furthermore, cohesive/non-cohesive mixtures were also detected. Their occurrence is a result of flood periods that had taken place in the past. In some sectors also organic soils were occurred, usually covered by younger sands. Additionally, soils are characterised by variation in the values of their mechanical parameters (Fig. 2).

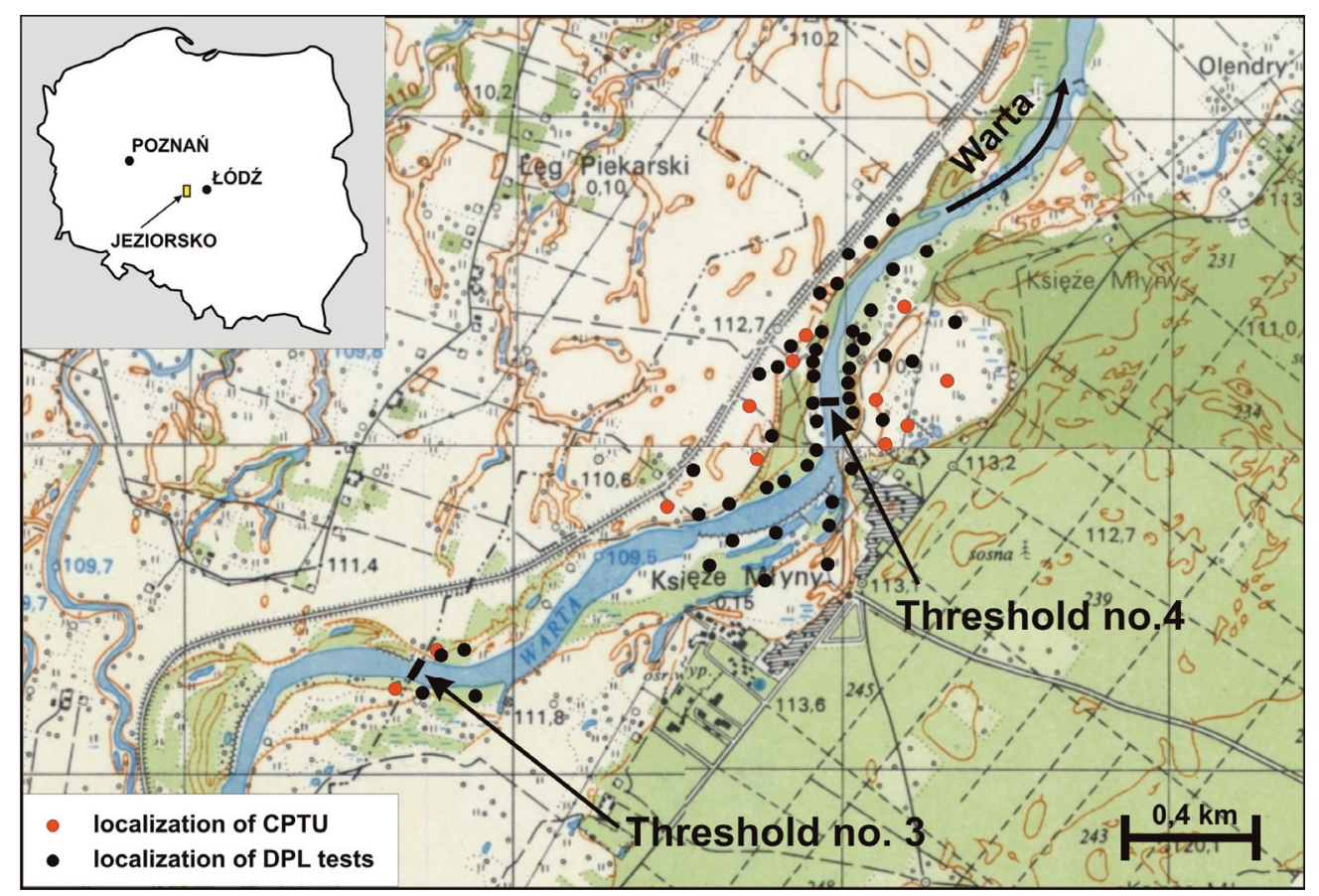

Fig. 1. Location of CPTU and DPL tests on topographic map (topographic maps of Pęczniew and Uniejów, OPGK Poznań, 1986, modified)

situ tests were carried out in the Warta River valley downstream the Jeziorsko reservoir (Fig. 1), where the average bed erosion rate was established to be $1 \mathrm{~m}$ per 10 years and reach about $18 \mathrm{~km}$ downstream the reservoir's dam. In order to stop the bed erosion process, four stabilizing thresholds were built. This resulted in that the scale of the longitudinal erosion process downstream the reservoir decreased in the area from the dam to the 4th threshold (Wierzbicki et al. [7]). However, it is still observed in further sections (downstream the threshold no. 4) and is threatening the stability of the bridge in Uniejów.

CPTU and DPL tests were carried out in floodplain terrace from 481 to $478,63 \mathrm{~km}$ reach of the river (Fig. 1). CPTU and DPL tests were conducted up to $10 \mathrm{~m}$ and $6 \mathrm{~m}$, respectively, below the surface, equally on each side of the river.

Results from CPTU indicate domination of noncohesive soils with very diversified grain size:

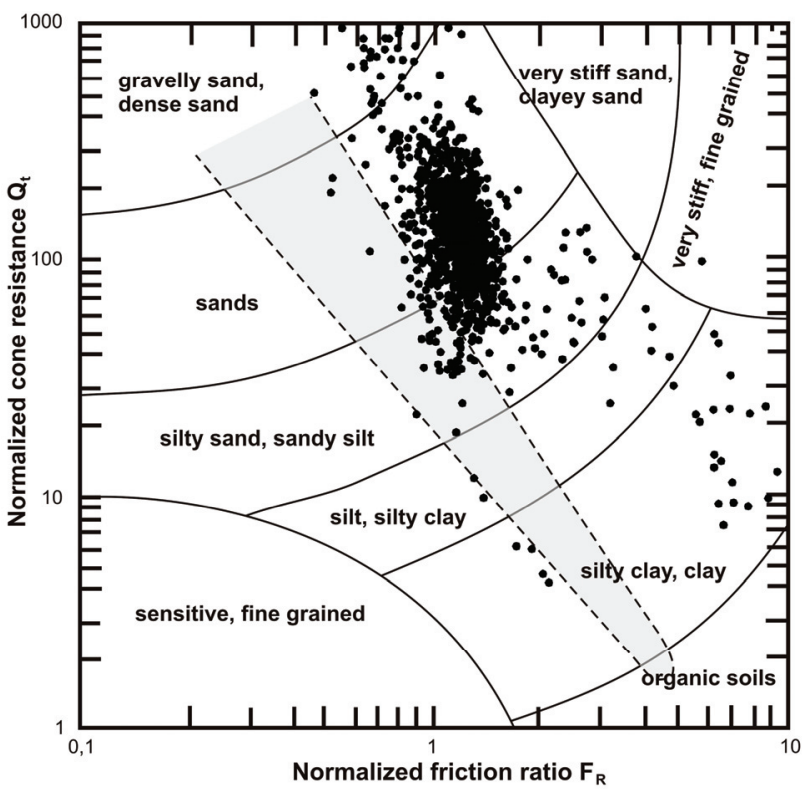

Fig. 2. Tested soils on the CPTU soil behaviour chart by Robertson [5] 


\section{FACTORS INFLUENCING THE BED EROSION}

The erosion process can be referred to a situation when soils lose their shear strength and particles detach from each other. Consequently, the erosion could be described by the following geotechnical parameters:

- mechanical - cohesion $(c)$, friction angle $(\varphi)$, undrained shear strength $\left(s_{u}\right)$,

- physical - plasticity index $\left(I_{p}\right)$, relative density $\left(I_{D}\right)$, grain size diversity.

Hence, depending on type of soils, different parameters have influence on the bed erosion rate.

The erosion resistance, in the case of cohesionless soils, is correlated with particle size and shape, of sediment particles $\left(\rho_{d}\right)$, sediment consolidation coefficient $\left(c_{v}\right)$, cohesion $(c)$ and the median particle diameter $\left(d_{50}\right)$.

\subsection{PARAMETERS OF THE MODEL BASED ON DPL RESULTS}

To create an experimental model of the erosion rate based on DPL results for non-cohesive subsoils the author made some modifications in the general model for cohesive soils (1) which are presented in Fig. 3. It is assumed that in the case of noncohesive soils $\tau_{c}, \rho_{d}$ are identified with $I_{D}$ (relative density), $c_{v}$ with $e$ (porosity), $\tau_{b}$ with $Q$ (river flow), and $c$ equals 0 . Only the characteristic diameter $d_{50}$ is preserved.

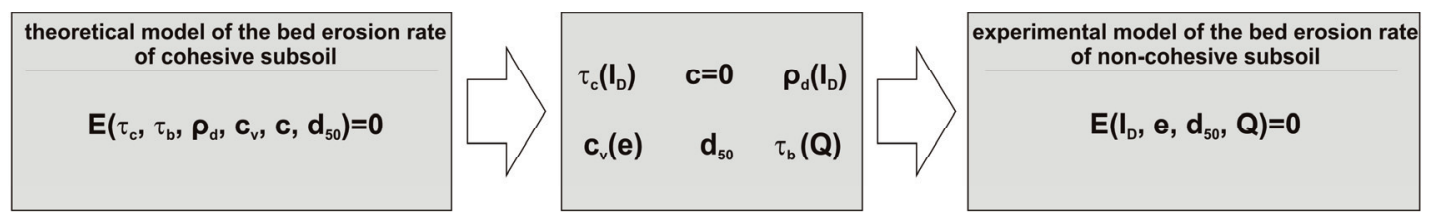

Fig. 3. Diagram of experimental model of the bed erosion rate for non-cohesive subsoil construction, based on assumptions made in the theoretical model of the bed erosion rate for cohesive subsoil

porosity and density. These soils are eroded particle by particle when the critical shear stress equals $0.1-$ $5 \mathrm{~N} / \mathrm{m}^{2}$ (Briaud et al. [1]). The critical shear stress $\tau_{c}\left[\mathrm{~N} / \mathrm{m}^{2}\right]$ is a parameter characterising the erosion resistance of soils and depends on geotechnical parameters of soils. It can be estimated based on Briaud et al. [1], Dunn (YongHui et al. [8]), Otsubo and Muraoko (YongHui et al. [8]), Smerdon and Beasley (Jacobs et al. [2]) equations. However, it should be remembered that these equations are empirical and should not be used as general formulas. Considering the above, the usage of the basic geotechnical parameters appears to be more appropriate.

\section{METHODOLOGY}

To create the multidimensional models of the bed erosion rate of the non-cohesive subsoil the author modified the existing, general model (1) for cohesive soils [8]

$$
E\left(\tau_{c}, \tau_{b}, \rho_{d}, c_{v}, c, d_{50}\right)=0 .
$$

The general model (1) assumes that the erosion rate, in the case of cohesion soils, depends on the critical shear stress for erosion $\left(\tau_{c}\right)$, the shear stress caused by the flow $\left(\tau_{b}\right)$ (hydraulic parameter), density
After these modifications, the experimental model of the erosion rate for non-cohesive soils was built (2)

$$
E\left(I_{D}, e, d_{50}, Q\right)=0 .
$$

Consequently, in this case the erosion rate depends on relative density $\left(I_{D}\right)$, porosity $(e)$, diameter of particles $\left(d_{50}\right)$ and river flow $(Q)$. To simplify the model the porosity was omitted in favour of another grain size $-d_{90}$ (because the porosity is a derivative of the grain size diversity)

$$
E\left(I_{D}, d_{50}, d_{90}, Q\right)=0
$$

where: $I_{D}$ - relative density [-], $d_{50}, d_{90}$ - diameter of particle $[\mathrm{mm}], Q-$ river flow $\left[\mathrm{m}^{3} / \mathrm{s}\right]$.

\subsection{PARAMETERS OF THE MODEL BASED ON CPTU RESULTS}

To analyse the influence of strength properties of subsoil on the bed erosion rate CPTU parameters $\left(q_{t}, Q_{t}\right.$, $F_{r}, f_{s}$ ) were added to proposed experimental model (3) in place of relative density (as a function of $\tau_{c}$ and $\rho_{d}$ from equation (1)). Therefore, the more complex relationship was created (4)

$$
E\left(Q, d_{50}, d_{90}, q_{t}, Q_{t}, F_{r}, f_{s}\right)=0
$$


where: $q_{t}-$ corrected cone resistance $[\mathrm{Pa}], Q_{t}-$ normalized cone resistance $[-], f_{s}-$ sleeve friction $[\mathrm{Pa}]$, $F_{r}$ - normalized friction ratio [-], $d_{50}, d_{90}$ - diameter of particle [mm], $Q$ - river flow $\left[\mathrm{m}^{3} / \mathrm{s}\right]$.

Initially, CPTU parameters were correlated with the erosion rate separately. That was the first step of the analysis. After this step, the pre-established number of parameters was reduced, based on verification of the strength of the correlation between the erosion rate and particular CPTU parameter. Further analysis includes only the most significant CPTU parameter correlated with river flow and grain size diversity.

\subsection{PROCEDURE FOR OBTAINING DATA}

Parameters characterising the subsoil were obtained from particular depth intervals. These intervals were defined by the depth and thickness of the eroded layer of soil in the river channel. Average values of geotechnical and CPTU parameters for these intervals were taken from two tests localised on opposite river banks (Fig. 1).

The bed erosion rate was established based on average changes of the river bed determined for every one year in a period from 2006 to 2010. Values of the bed erosion rate are estimated at $0.05-0.68 \mathrm{~m} / \mathrm{a}$.

The river flow and characteristic diameters of grains were taken from field tests carried out in 19952008. Results of these tests were published by Wierzbicki et al. [7].

Based on DPL results relative density was estimated (5). The author used standardised relationship [4]

$$
I_{D}=0.071+0.429 \log N_{10}
$$

where: $I_{D}$ - relative density, $N_{10}$ - number of strokes on $10 \mathrm{~cm}$ of immersion of the tip.

CPTU parameters were obtained directly from the tests. Some parameters were taken into consideration: $q_{t}-$ corrected cone resistance (6), $Q_{t}$ - normalized cone resistance (7), $f_{s}$ - sleeve friction (directly from the test), $F_{r}$ - normalized friction ratio (8)

$$
\begin{gathered}
q_{t}=q_{c}+(1-a) u_{2}, \\
Q_{t}=\frac{q_{t}-\sigma_{v 0}}{\sigma_{v 0}^{\prime}}, \\
F_{r}=\frac{f_{s}}{q_{t}-\sigma_{v 0}} \cdot 100 \%,
\end{gathered}
$$

where: $q_{c}$ - cone resistance, $a$ - net area ratio, $u_{2}$ - pore pressure measured between the cone tip and the friction sleeve, $\sigma_{v 0}$ - total vertical stress, $\sigma_{v 0}^{\prime}-$ vertical effective stress.

\section{ANALYSIS AND DISSCUSION OF RESULTS}

According to the previous assumptions (3), (4), all parameters mentioned were correlated to the bed erosion rate separately. Afterwards, some other parameters characterising the soil or the flow were added to the model.

\subsection{THE BED EROSION MODEL - RESULTS OF DPL TESTS}

Correlation between the bed erosion rate and relative density shows two groups of observations (Fig. 4A). In both groups values of relative density are inversely proportional to the bed erosion rate. Group A represents observations from stretch downstream threshold no. 4 and group B observations between thresholds no. 3 and 4. This dispersal of observation suggests that other parameters have significant influence on the bed erosion rate. As a consequence, river flow and grain diameters were added to the model (3) (Fig. 4B).

Size of the grains is the main factor causing the differences between the groups (Fig. 4B). The influence of river flow is also visible. The highest bed erosion rate is observed in a zone where the river flow is bigger than $47 \mathrm{~m}^{3} / \mathrm{s}$. It seems that the geotechnical parameters influence the erosion rate only for smaller values of the river flow - in this case lower than $47 \mathrm{~m}^{3} / \mathrm{s}$ (Fig. 4B).

\subsection{THE BED EROSION MODEL - CPTU RESULTS}

All selected CPTU parameters were also correlated to the bed erosion rate separately. Firstly, the author analysed the influence of corrected cone resistance and sleeve friction. The correlations are presented in the diagrams (Fig. 5).

These diagrams are similar in the aspect of distribution of observations, which are scattered, but the general trend can be determined: the lower the values of corrected cone resistance and sleeve friction, the bigger the bed erosion rate. 

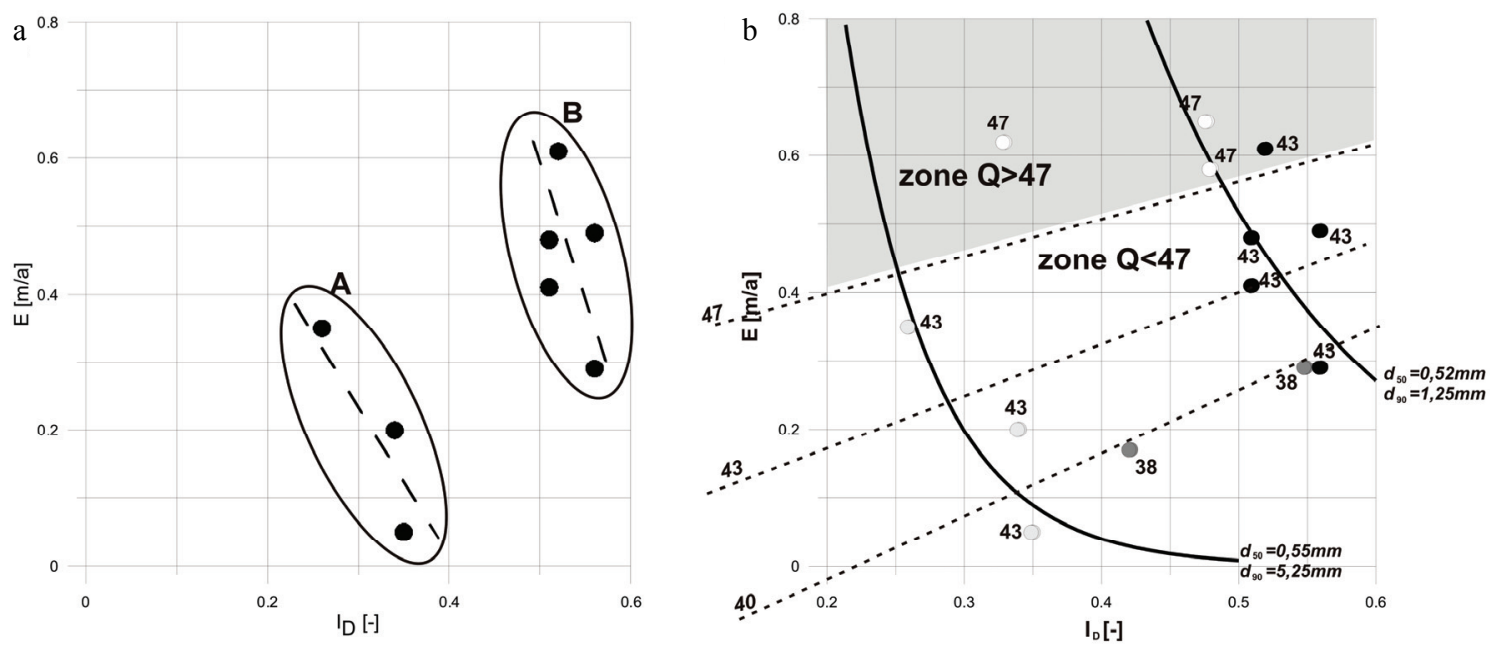

Fig. 4. DPL results: a - diagram of the correlation of relative density with the bed erosion rate; $\mathrm{b}$ - the multidimensional model of the bed erosion rate based on relative density and the river flow (unpublished, assumptions of the model were presented at XIV Scientific Conference for Civil Engineering PhD Students in Szczyrk in May 2014)
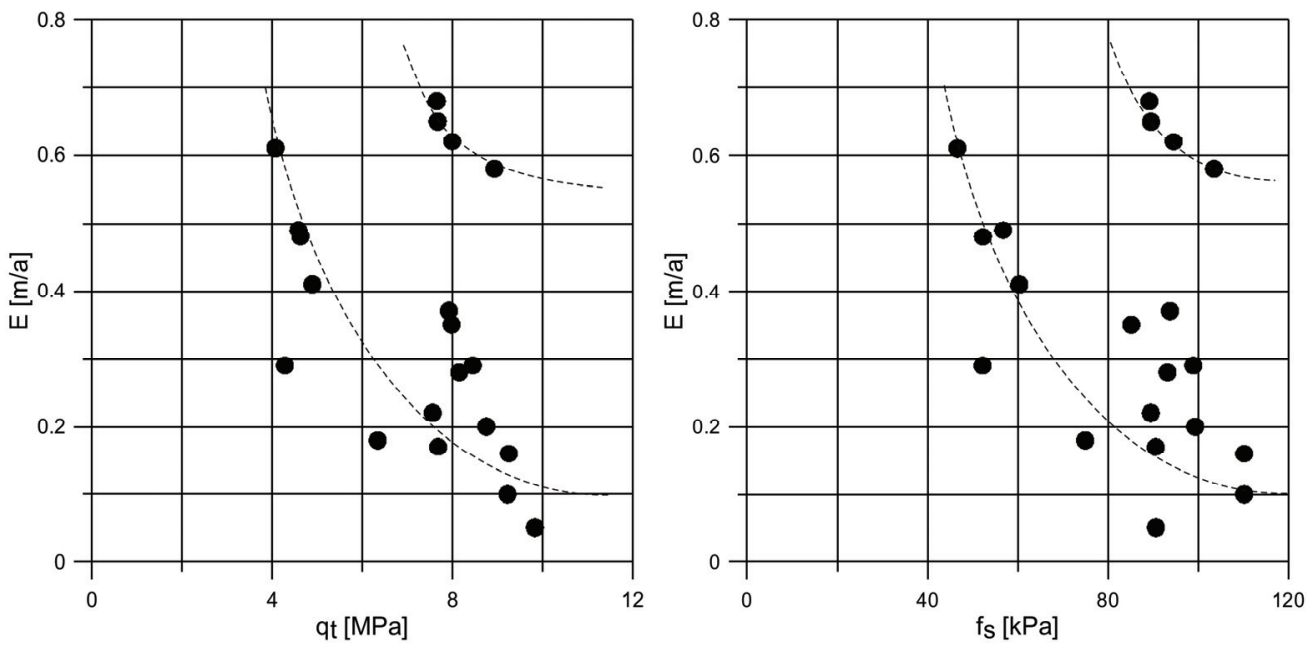

Fig. 5. Diagrams of the correlation of corrected cone resistance and sleeve friction with the bed erosion rate

In the next step, the influence of effective vertical stress was examined by analysing normalized cone resistance and normalized friction ratio. Results of this analysis are shown in Fig. 6.

In the case of normalized cone resistance values, the distribution of observations is similar to the diagram of corrected cone resistance. This proves that influence of parameter normalization is not relevant on this depth (2-5 meters). Furthermore, based at this comparison it can be concluded that the effective vertical stress does not affect the bed erosion rate. This means that the bed erosion is a surface process, with the effective vertical stress equal 0.

The diagram of normalized friction ratio shows a very small variation in the values. This homogeneous structure of values makes the analysis of this parameter influence on the bed erosion rate impossible.
The small variation of normalized friction ratio values and comparable distribution of observations from diagrams of normalized and corrected cone resistance and friction sleeve allow some parameters to be neglected in the bed erosion model.

Based on the analysis of the correlation of CPTU parameters on the bed erosion rate the author verified the model (4) and proposed a more simplified (9) with normalized cone resistance.

$$
E\left(Q, d_{50}, d_{90}, Q_{t}\right)=0
$$

The results of the multidimensional analysis are presented on the diagram (Fig. 7).

The model (Fig. 7) shows the simultaneous correlation of normalized cone resistance, grain size and river flow with the bed erosion rate. Values of the river flow are divided into two zones. The limit value 

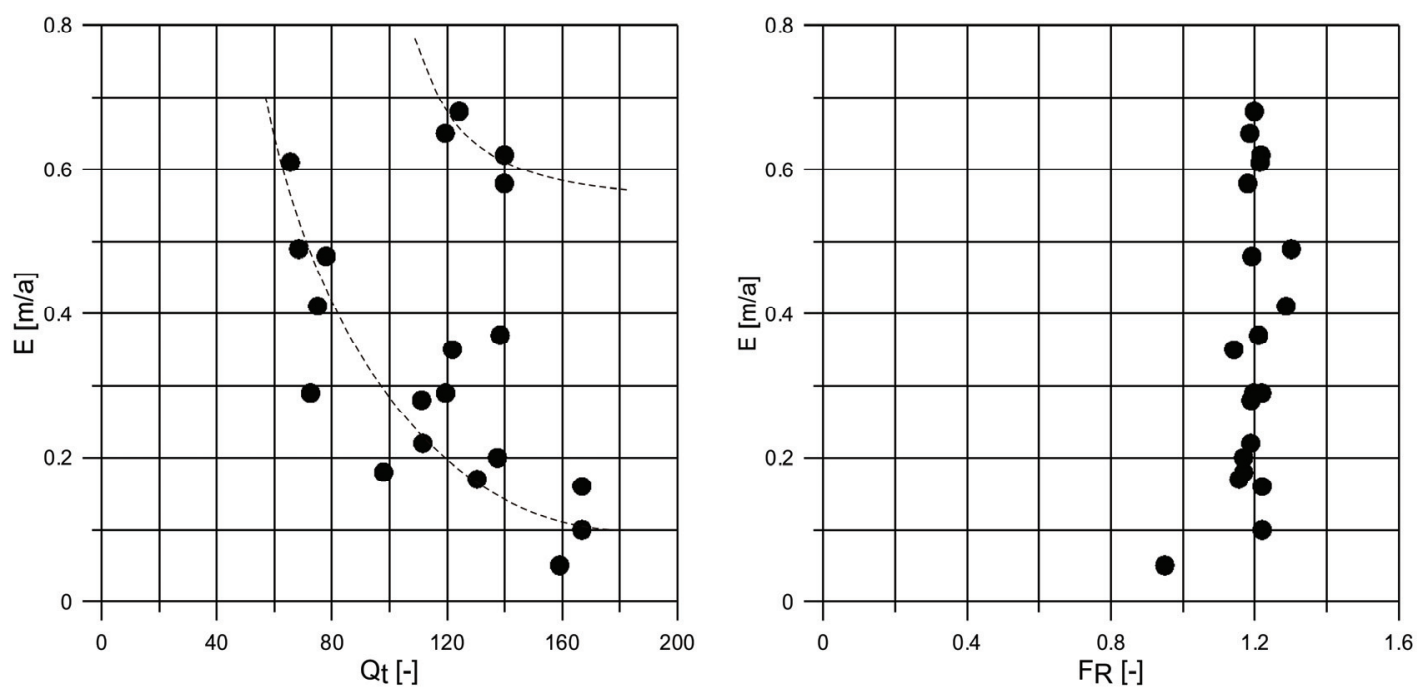

Fig. 6. Diagrams of the correlation of normalized cone resistance and normalized friction ratio with the bed erosion rate

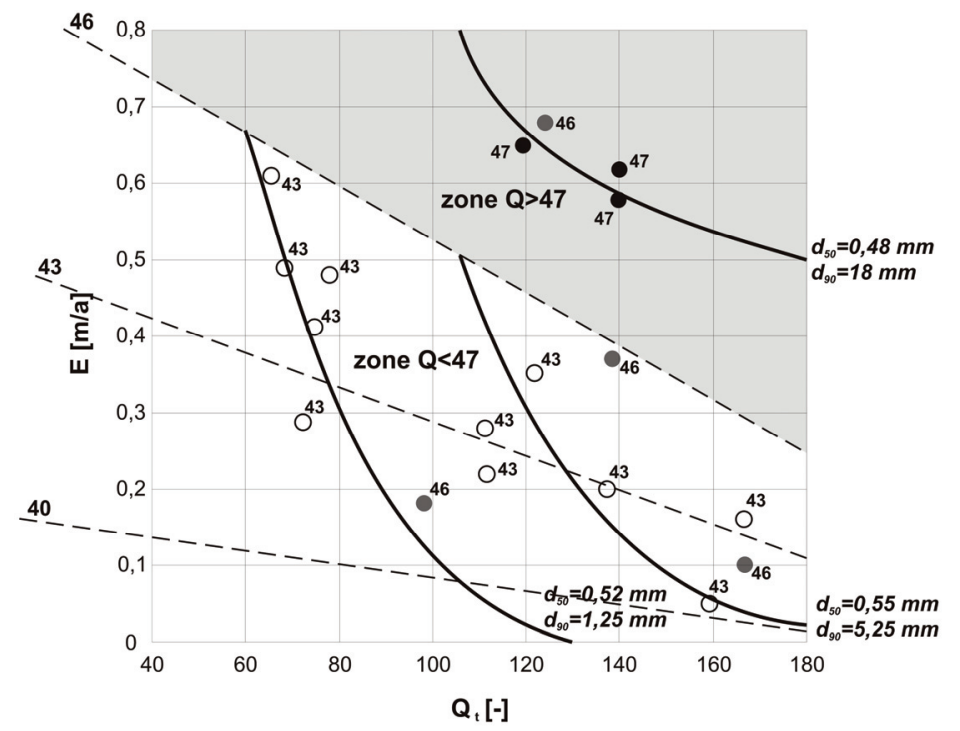

Fig. 7. The multidimensional model of the bed erosion rate based on CPTU parameter and the river flow

was estimated at $47 \mathrm{~m}^{3} / \mathrm{s}$. In a zone where $Q>$ $47 \mathrm{~m}^{3} / \mathrm{s}$, the river flow has the biggest influence on the bed erosion rate (grain sizes and normalized cone resistance do not have an impact on the bed erosion rate). In zone with lower values of the river flow observations are divided based on grain sizes. Finer soils become eroded more quickly. Furthermore, in this zone the values of CPTU parameter have the most significant importance in the case of the erosion process.

\section{CONCLUSIONS}

The bed erosion process is a complex phenomenon. Intensity of this process depends not only on the river flow, but also on geoengineering properties of soils occurring in the river valley. In the paper, an attempt was made to build the bed erosion rate models based on geotechnical and CPTU parameters.

During the analysis, relative density, normalized cone resistance, corrected cone resistance, sleeve friction and normalized friction ratio were taken into the consideration. Normalized cone resistance, corrected cone resistance and sleeve friction have very similar results of correlation with the bed erosion rate. Based on this comparison it could be concluded that effective vertical stress does not affect the bed erosion rate. This means that the bed erosion is a surface process, where effective vertical stress equals 0 , whereas values of normalized friction ratio are basically the same in all observations 
in this area. That is why this parameter could be neglected in further analysis.

The multidimensional models were built based on relative density, normalized cone resistance, river flow and grain sizes. Furthermore, the models indicate the existence of the limit value for the river flow. Above this characteristic value, other parameters do not have significant importance in the case of the bed erosion rate.

To improve the models, some other parameters could be included, for example, characteristic structure and texture of the soils (Młynarek [3]; Wierzbicki and Stefaniak [6]) as well as hydraulic parameters.

\section{REFERENCES}

[1] Briaud J.-L., Chen H.-C., Nurtjahyo Y., Li P., Wang J., Complex pier scour and contraction scour in cohesive soils, Transportation Research Board National Research Council. (NCHRP REPORT 24-15, 2003).

[2] Jacobs W., Le Hir P., VAn Kesteren W., Cann P., Erosion threshold of sand - mud mixtures, Continental Shelf Research, 2011, 31, 14-25. DOI: 10.1016/j.crs.2010.05.012.
[3] MŁynareK Z., Czynniki wptywajqce na opór stożka podczas statycznego sondowania gruntów spoistych, Poznań: Roczniki Akademii Rolniczej, 1978.

[4] Polish standards committee. (2002). Geotechnika - Badania polowe, PN-B-04452, Poland.

[5] ROBERTSON P.K., Interpretation of cone penetration tests - a unified approach, Canadian Geotechnical Journal, 2009, 46 (11), 1337-1355, DOI: 10.1139/T09-065.

[6] WIERZBICKI J., STEFANIAK K., Ocena wptywu struktury i tekstury gruntu niespoistego na opór stożka w badaniu CPTU, [in:] E. Dembicki, M.K. Kumor, Z.M. Lechowicz (eds.), Problemy geotechniczne i środowiskowe z uwzględnieniem podloży ekspansywnych, Wydawnictwa Uczelniane UTP, Bydgoszcz, 2009, 117-128.

[7] Wierzbicki M., Hämmerling M., Przedwojski B., Wpływ budowy progów stabilizujacych na ksztattowanie się uktadu zwierciadta wody $i$ dna ponizej zbiornika Jeziorsko, Gospodarka Wodna, 2011, 6, 239-243.

[8] Yong Hui Z., Jin You L., Hong Zhi L., Jia Sheng W., Bei Lin F., SHI MING Y., (2008), Research on cohesive sediment erosion by flow: An overview. Science in China Series E: Technological Sciences. 51(11), 2001-2012, DOI: 10.1007/s11431008-0232-4.

[9] ZIELIŃSKI T., Sedymentologia. Osady rzek i jezior, Wydawnictwo Naukowe Uniwersytetu im. Adama Mickiewicza w Poznaniu, Poznań, 2014. 